\title{
Enhancing oil recovery through nanofluids flooding with Irvingia gabonensis in the Niger Delta
}

\author{
J. C. Onyemachi' ${ }^{1}$ - S. I. Onwukwe ${ }^{1} \cdot$ Ugochukwu llozurike Duru' $^{1}$ A. O. Chikwe ${ }^{1} \cdot$ N. Uwaezuoke $^{1}$
}

Received: 11 March 2020 / Accepted: 6 July 2020 / Published online: 17 July 2020

(c) The Author(s) 2020

\begin{abstract}
Application of nanofluids flooding in the oil and gas industry is recently emerging as enhanced oil recovery methods. Nanoparticles have the ability to alter the rock formation in order to recover oil trapped in the pores of the rock to improve oil recovery. In this study, core plug samples were formulated in the laboratory to investigate the effect of nanoparticles on oil recovery. The formulated core samples were saturated in low salinity brine. However, low salinity brine was used because it has the ability to alter rock wettability. After core flooding with brine for secondary recovery process, extracted oil from Irvingia gabonensis was introduced into the formation to investigate the effect of Irvingia gabonensis on oil recovery. The result of the study showed that magnesium oxide, silicon oxide, aluminum oxide and zinc oxide had oil recovery of $38.1 \%$, $45.6 \%, 47.7 \%$ and $35.1 \%$, respectively. However, when the nanofluids with Irvingia gabonensis were injected into the formation as a displacing agent, the oil recovery greatly improved to $50.3 \%, 52.0 \%, 53.2 \%$ and $52.4 \%$ for $\left(\mathrm{MgO}, \mathrm{SiO}_{2}, \mathrm{Al}_{2} \mathrm{O}_{3}\right.$ and $\mathrm{ZnO}$ ). The result of the study showed that nanofluid flooding is a promising potential to improve oil recovery in the Niger Delta.
\end{abstract}

Keywords Magnesium oxide $\cdot$ Silicon oxide $\cdot$ Aluminum oxide $\cdot$ Zinc oxide $\cdot$ Irvingia gabonensis $\cdot$ Nanoparticles Nanofluids

\section{Introduction}

Nanoparticles (NP) are usually made up of core and thin shell, and the thin shell is composed of inorganic materials which is different from the core, but the physiochemical properties of NPs are always controlled by the properties of the core (Das et al. 2008; Virkutyte and Varma 2012). NPs

J. C. Onyemachi

joshuaonyemachi1@gmail.com

S. I. Onwukwe

mooremsi1@gmail.com

Ugochukwu Ilozurike Duru

ugochukwu.duru@futo.edu.ng

A. O. Chikwe

anthony.chikwe@futo.edu.ng

N. Uwaezuoke

nnaemeka.uwaezuoke@futo.edu.ng

1 Petroleum Engineering Department, Federal University of Technology, Owerri, Nigeria are known to possess high thermal and mechanical stability, and they can be modified or tailored to fit the specifications of any given reservoir system. Also, NPs have the capacity to withstand high pressures, temperatures, shear and salinity which is the predominant condition in the subsurface reservoir system, hence making them suitable for EOR processes (Andreassen 2015; Bennestien and Mogensen 2014).

Application of nanofluids flooding is recently emerging as enhanced oil recovery (EOR) methods (Ogolo et al. 2012). Current research work has shown that nanoparticles have the potential to solve several problems in the petroleum industry Chengara et al. (2004). One of the areas being speculated for application of nanoparticles is the area of enhanced oil recovery (EOR) application. Enhanced oil recovery is important because of the recent global rising demand for energy to be met in the petroleum industry. Lot of researches have been conducted to ascertain the efficiency or effectiveness of nanoparticle in EOR operations. Silica-based nanoparticles are the most researched among other nanoparticles, hence the study of other metal oxides such as $\mathrm{MgO}, \mathrm{ZnO}$, $\mathrm{Al}_{2} \mathrm{O}_{3}$ and Irvingia gabonensis. 


\section{Literature review}

Nanoparticles are considered to be an excellent option in EOR process owing to the following: They are cheap and eco-friendly. They are easily modified or tailored to enhance desirable properties such as wettability alteration, increase mobility and reduce surface tension. They move through porous media without plugging the pore throat. Metallic NPs can be separated from oil using magnetic separation. NPs have a high surface-to-volume ratio which results in enhanced thermal properties.

Nanoparticles have the ability to alter some factors in the formation to enhance recovery Wasan et al. (2011). This involves introducing these nanoparticles into formations and studying its effect on oil recovery. The oil and gas industry might face the challenges to unlock the resources that are becoming increasingly difficult to reach with conventional technology. Most oil fields around the world have achieved the stage where the total production rate is nearing the decline phase. Hence, the current major challenge is how to delay the abandonment by extracting more oil economically. A nanoparticle as a part of nanotechnology has size typically less than $100 \mathrm{~nm}$, and its size is much smaller than rock pore throat in micron size (Luky et al. 2012). A nanoparticle fluid suspension, so-called nanofluid, is synthesized from nano-sized particles and dispersed in liquids such as water, oil or ethylene glycol. The continuous increase in publication addressed on the topic; nanofluid flooding has showed its potential as improved oil recovery or enhanced oil recovery (IOR/ EOR) in the oil and gas industry (Huang et al. 2009). It has motivated researchers to perform experimental study to reveal the recovery mechanism and performance of nanofluid in porous medium. Miranda et al. (2012) mentioned the benefit of using silica nanoparticles. They reported that nanoparticles are inorganic materials that are easily produced with a good degree of control/modification of physical chemistry properties. It can also be easily surface functionalized from hydrophobic to hydrophilic by silanization with hydroxyl group or sulfonic acid. Madhan et al. (2014), Ogolo et al. (2012) reported that silica, aluminum oxides, zinc oxide, nickel oxide, titanium oxide, zinc oxide, zirconium oxide and magnesium oxide have the ability to increase oil recovery. In addition, their work noted that the mechanisms of the nanoparticles in the EOR processes are wettability alteration, interfacial tension reduction and viscosity control. Hendraningrat et al. $(2012,2013)$ in their work reported that nanoparticles can be used as an enhanced oil recovery method. Nanoparticles (NPs) dispersed in water were able to enhance oil recovery in various core floods through displacement mechanisms. They further suggested that interfacial tension (IFT) reduction and wettability alteration are the main reason behind the improved oil recovery.

For nanoparticles to be utilized in EOR process, they must be converted to nanofluids. Nanofluids are nanoparticles dissolved in a heat transfer fluid or displacing medium like water or oil (Das et al. 2008). The commonly used nanoparticle for the production of nanofluids is the oxides of zinc, silicon, aluminum, magnesium, zirconium, tin, iron and nickel (Ogolo et al. 2012; Zhang et al. 2010).

Ahamdi et al. (2013) conducted a study on other forms of nanoparticles $\left(\mathrm{MgO}\right.$ and $\left.\mathrm{Al}_{2} \mathrm{O}_{3}\right)$ and compared it with silicon oxide. Their result shows that $\mathrm{MgO}$ has the most tendency to reduce fine migration by coating or attaching the fines to surface.

Hendraningrat and Torsaeter (2014) investigated the stability of metal oxides nanoparticles, and aluminum oxides and magnesium oxides were the nanoparticles of consideration. They discovered that addition of dispersants improves the stability of nanoparticles. Povidone (PVP) was the dispersant utilized; this dispersant alters the properties of the metal oxides ( $\mathrm{pH}$ and surface conductivity) which leads to improved nanoparticle stability. It was also observed that the combination of dispersant and nanoparticles increases the oil recovery and metal oxides alter wettability to make water more wet.

Nwldee et al. (2016) also conducted a study on oil-wet rock (limestone) to ascertain the ability of zirconium oxide (nanoparticle) to alter the wettability of oil-wet rock. They discovered that a concentration of $0.05 \mathrm{wt} \%$ of $\mathrm{ZrO}_{2}$ nanofluid was able to alter the wettability of calcite substrate (strongly oil-wet rock) with a contact angle of $152^{\circ}-44^{\circ}$ (strongly water wet); with this ability, $\mathrm{ZrO}_{2}$ is a good agent for EOR operations.

Ogolo et al. (2013) investigated the ability of nanoparticles to trap migrating fines in a sandstone formation. They conducted their study using distill water, brine and ethanol as the base fluid; from their results, we can deduce that aluminum oxide has the most capacity to trap fines. They also concluded that $\mathrm{pH}$ value and electrostatic force of adsorption were the mechanisms responsible for the trapping of fines. This also highlights metal oxides nanoparticle as a potential agent in EOR process.

Muhammed (2016) explored a combination of nanoparticle and polymer to assess its recovery potentials, using aluminum oxide and polyacrylamide. From his result, the following can be deduced: firstly, a $2 \%$ increase in R.F of OOIP after polymer flooding. Secondly, the RF of nano-polymer (combination of polymer and nanoparticles) flooding gave $66.29 \%$ OOIP and $40 \%$ reduction in cost, a little bit lower than the RF of polymer flooding which was $67.16 \%$; thirdly, the combination also alters the wettability to a more water-wet. 
Tola et al. (2017) investigated wettability alteration of sandstone using nanofluids formulated with $\mathrm{ZnO}$ nanoparticles. The $\mathrm{ZnO}$ nanofluid was mixed by dispersing into water solution of sodium dodecyl sulfate, and the concentration (w/w) of $\mathrm{ZnO}$ ranges from 500 to $5000 \mathrm{ppm}$. From their study, it was confirmed that the $\mathrm{ZnO}$ nanofluid has a potential to shift wettability to more water wet condition on the surfaces of oil film and sandstone saturated by oil.

\section{Methodology}

\section{Materials}

The materials used to conduct the experiment include the following:
1. Irvingia gabonensis (ogbono)
2. Magnesium oxide $(\mathrm{MgO})$
3. Silicon oxide $\left(\mathrm{SiO}_{2}\right)$
4. Zinc oxide $(\mathrm{ZnO})$
5. Aluminum oxide $\left(\mathrm{Al}_{2} \mathrm{O}_{3}\right)$
6. Sand
7. Crude oil
8. Brine
9. Core sample

\section{Methods}

\section{Sample collection}

The nanoparticles and Irvingia gabonensis (ogbono) used for this research study were bought from Onitsha International Market, Anambra State, Nigeria. The nanoparticles sizes are given in Table 1. The four different sizes of the nanoparticles used for this study were chosen for the EOR experiment because of the potentials property they have to solve reservoir formations problems. Figures 1, 2, 3, 4 and 5 show the nanofluid particles and Irvingia gabonensis (ogbono), the core plugs and the apparatus-setup used for the study (Fig. 6).

Table 1 Properties of the nanofluid particles used in the experiment

\begin{tabular}{lll}
\hline Number & Types of nanoparticles & $\begin{array}{l}\text { Particle } \\
\text { size } \\
\text { (micros) }\end{array}$ \\
\hline 1 & Magnesium oxide & 20 \\
2 & Silicon oxide & $15-18$ \\
3 & Aluminum oxide & 30 \\
4 & Zinc oxide & 20 \\
\hline
\end{tabular}

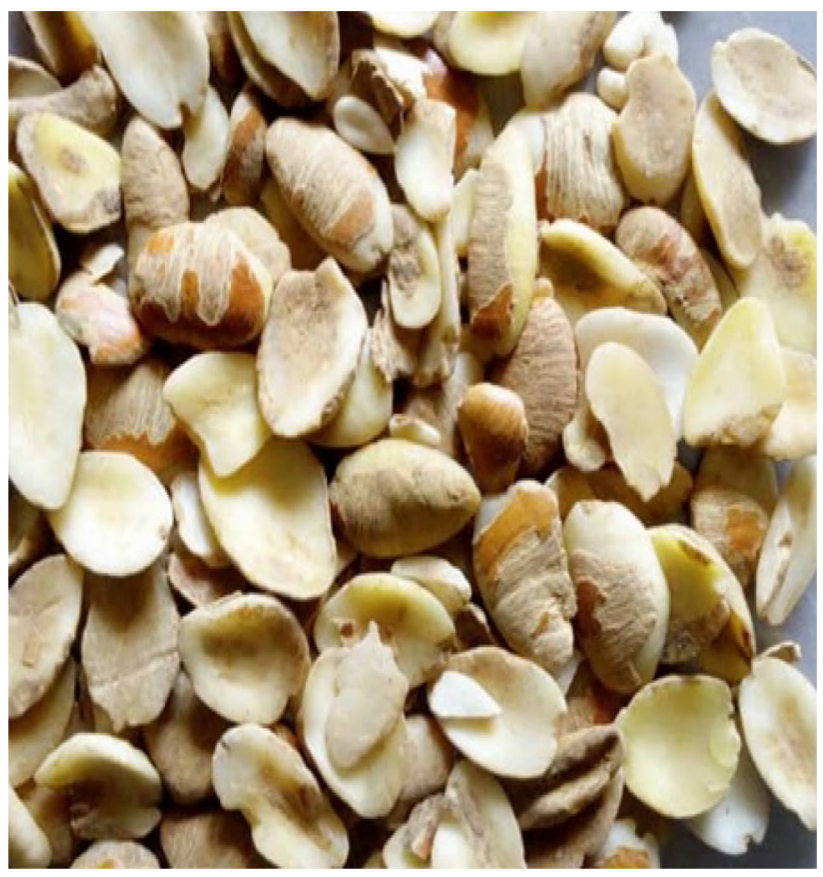

Fig. 1 Sample of the Irvingia gabonensis (ogbono)

\section{Processing of the Irvingia gabonensis (Ogbono)}

The local Irvingia gabonensis (ogbono) was gotten from Owerri cluster market in Imo State Nigeria. It was stored in a bag to avoid bacterial attack. In addition, it was sundry to

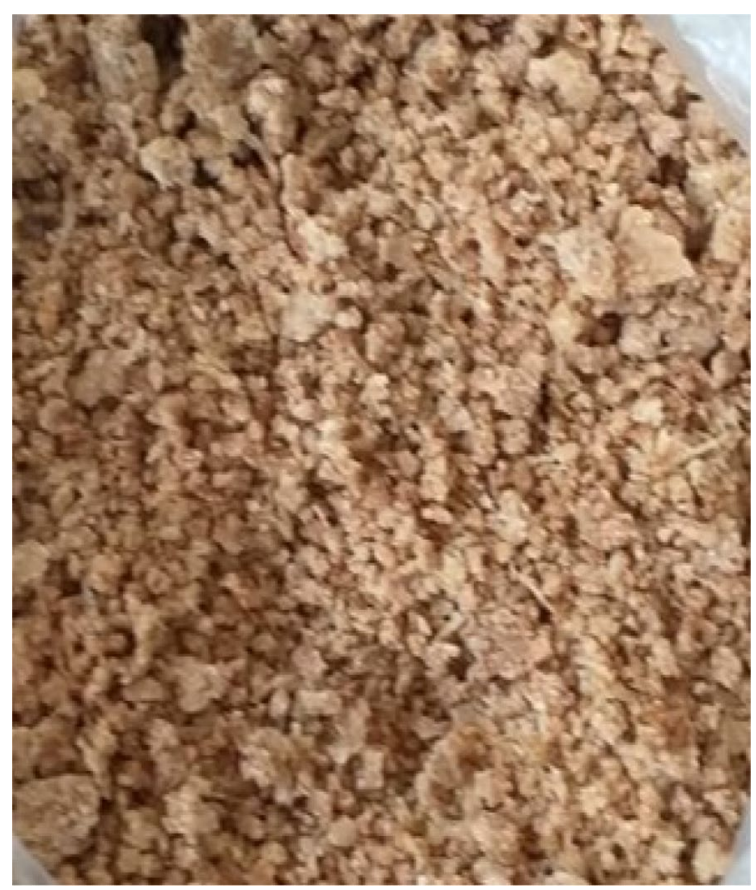

Fig. 2 Sample of the grounded Irvingia gabonensis (ogbono)

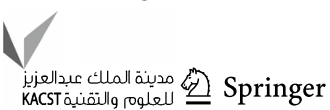




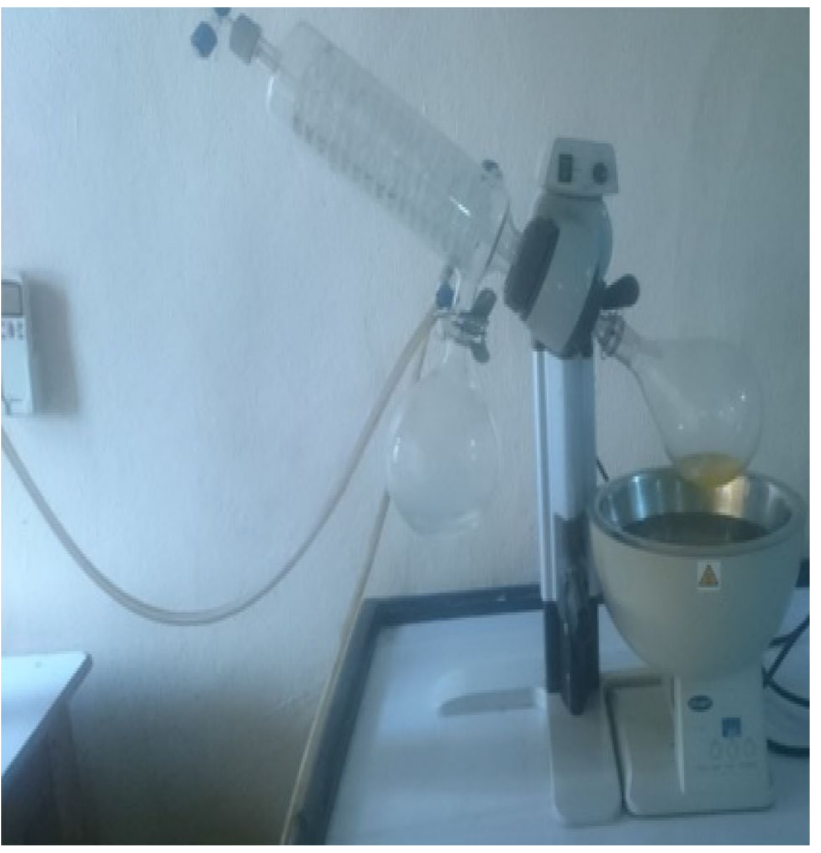

Fig. 3 Extracted oil from the Irvingia gabonensis (ogbono)

remove the moisture content before being used for the experimental study. Figure 7 shows the sample of the grounded Irvingia gabonensis (ogbono).

\section{Laboratory preparation of the Irvingia gabonensis (ogbono)}

The local Irvingia gabonensis (ogbono) was grinded to a smaller particle and put in an oven to remove moisture and bacterial attack for $5 \mathrm{~min}$. It was put in a foil paper, and Soxhlet extractor was used to extract the oil from the Irvingia gabonensis (ogbono). It was connected to a heat source, and water was used beneath to stabilize the heat from the source.
Hexane was poured into the cylinder with the Soxhlet extraction to absorb the oil as shown in Fig. 3.

\section{Core formulation}

Core samples were formulated using unconsolidated sand in the Niger Delta. After drying the cores in an oven, it was packed in a foil as shown in Fig. 4.

\section{Procedure for the nanofluid flooding with Irvingia gabonensis (ogbono)}

In this research work, three sets of experiments were conducted.

Brine was injected into the beaker containing distilled water. However, oil was injected into the formation for secondary recovery method (waterflooding as a base case). In addition, the nanofluid particles were then injected to displace, flush and recover the oil. However, the nanofluid particles were introduced with Irvingia gabonensis (ogbono as local polymer) to investigate the effect of the nanofluid particles on oil recovery (Tables 2, 3, 4 and 5).

\section{Experimental process}

Core plug samples were saturated for 3 days to determine the porosity and permeability of the core samples. Low salinity brine was injected into the formation together with the core samples to determine the oil recovery as a secondary recovery mechanism (waterflooding) before the introduction of the nanoparticles as tertiary recovery methods. However, pump was used to inject, recover and flush the fluid in order to ascertain the produced effluents. Figure 5 shows the schematic diagram of the flooding process.

The displacement efficiency is calculated using this equation:

Fig. 4 Core plug samples

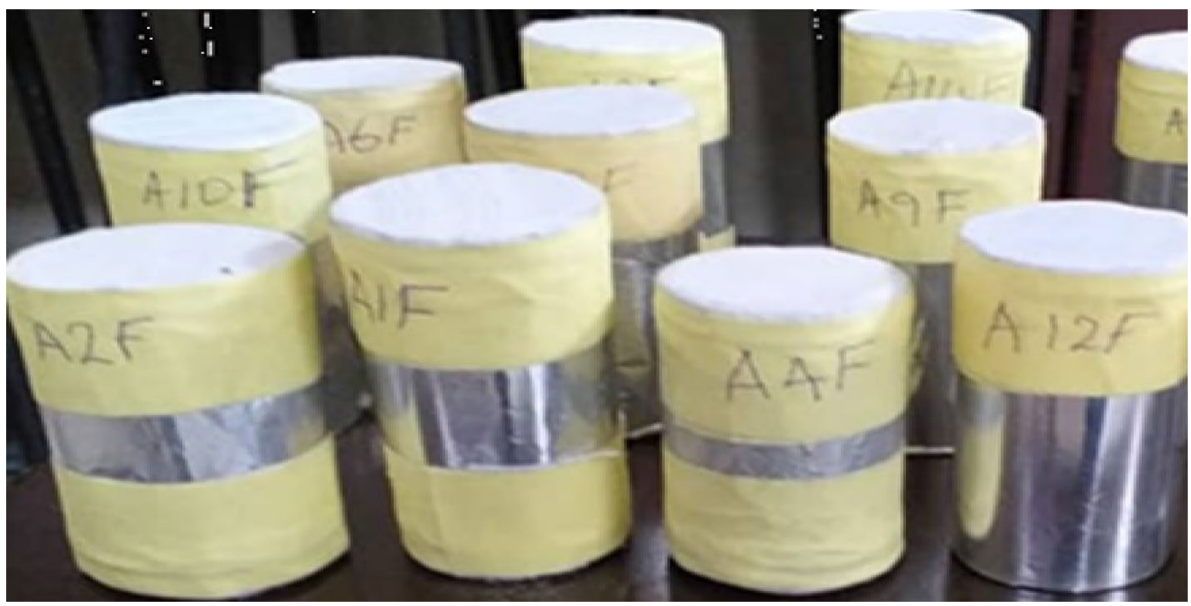


Fig. 5 Diagram of a nanofluid flooding

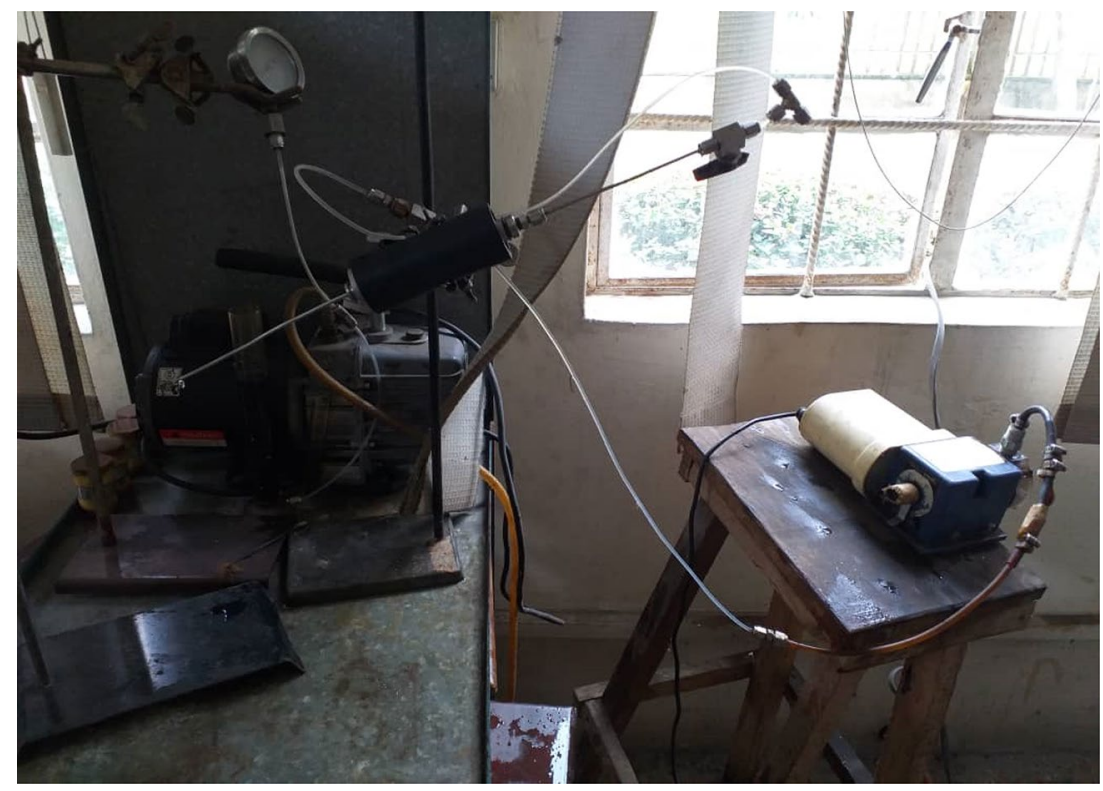

A graph of waterflood and nanofluid flood with ogbono

(Mgo)

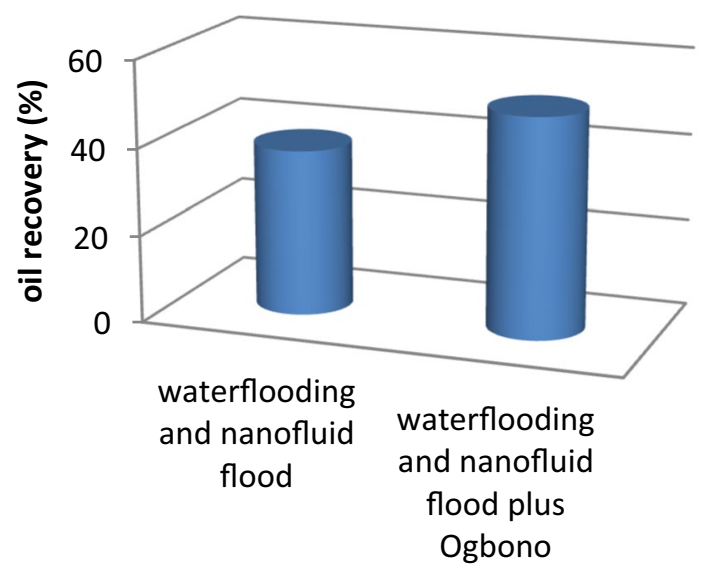

waterflood and nanofluid flood

Fig. 6 Oil recovery against waterflood and nanofluid flood

Displacement Efficiency $=\frac{X}{R_{0}} \times 100 \%$

where $X=$ oil in place $(\mathrm{rbbl}), R_{\mathrm{o}}=$ recovered oil $(\mathrm{rbbl})$

\section{Agraph of waterflood and nanofluid flood with ogbono (Sio2)}

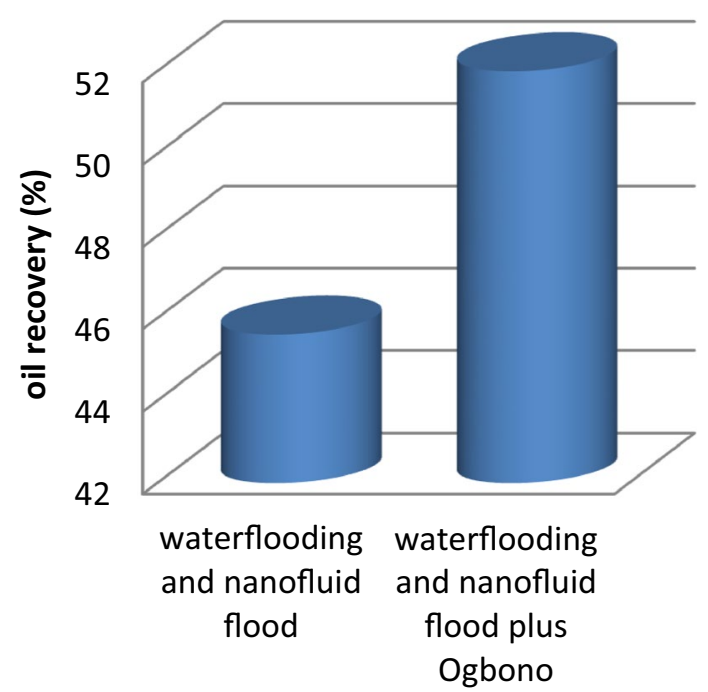

waterflood and nanofluid flood

Fig. 7 Oil recovery against waterflood and nanofluid flood

Table 2 Properties of the crude oil used in the experiment

\begin{tabular}{ll}
\hline Properties & Values \\
\hline Specific gravity & 0.8436 \\
Density & $0.8672 \mathrm{~g} / \mathrm{cm}^{2}$ \\
Viscosity of the crude oil & $1.27 \mathrm{cp}$ \\
Temperature & $29^{\circ}$ \\
API gravity of the oil & $29.23^{\circ}$ \\
\hline
\end{tabular}


Table 3 Properties of the core samples

\begin{tabular}{lllll}
\hline Samples & $\begin{array}{l}\text { Core sample } \\
\text { height }\left(\mathrm{cm}^{2}\right)\end{array}$ & $\begin{array}{l}\text { Core diam- } \\
\text { eter }\left(\mathrm{cm}^{2}\right)\end{array}$ & $\begin{array}{l}\text { Core } \\
\text { radius } \\
\left(\mathrm{cm}^{2}\right)\end{array}$ & $\begin{array}{l}\text { Bulk volume } \\
\left(\mathrm{cm}^{2}\right)\left(\pi \mathrm{r}^{2} \mathrm{~h}\right)\end{array}$ \\
\hline $\mathrm{A}_{1} \mathrm{~F}$ & 5.80 & 2.89 & 1.45 & 38.33 \\
$\mathrm{~A}_{2} \mathrm{~F}$ & 6.90 & 2.71 & 1.36 & 40.01 \\
$\mathrm{~A}_{3} \mathrm{~F}$ & 6.82 & 3.50 & 1.75 & 65.64 \\
$\mathrm{~A}_{4} \mathrm{~F}$ & 7.21 & 3.54 & 1.77 & 70.99 \\
$\mathrm{~A}_{5} \mathrm{~F}$ & 7.35 & 3.78 & 1.89 & 82.52 \\
$\mathrm{~A}_{6} \mathrm{~F}$ & 6.34 & 3.20 & 1.60 & 51.00 \\
$\mathrm{~A}_{7} \mathrm{~F}$ & 6.89 & 2.98 & 1.49 & 48.07 \\
$\mathrm{~A}_{8} \mathrm{~F}$ & 7.85 & 3.21 & 1.61 & 63.95 \\
\hline
\end{tabular}

\section{Results}

\section{Graphical result presentation of the nanofluid flooding}

\section{Discussion of result}

\section{Magnesium oxide (MgO)}

Table 6 shows the result of magnesium oxide. From the table, it can be observed that core $\left(\mathrm{A}_{1} \mathrm{~F}\right.$ and $\left.\mathrm{A}_{2} \mathrm{~F}\right)$ plus brine (waterflooding) recovered 5.9 and 6.2 from 16.0 to 15.3 oil in place. However, Irvingia gabonensis (ogbono) was injected into the formation which recovered additional 0.2 mil (1.3\%) that is $\mathrm{A}_{1} \mathrm{~F}+$ brine $+\mathrm{MgO}$. In addition, $\left(\mathrm{A}_{1} \mathrm{~F}+\right.$ brine $+\mathrm{MgO}+$ ogbono) recovered 1.5 mil (9.4\%). Figure 11 shows that waterflooding and nanofluid flooding had oil recovery of $38.1 \%$, while waterflooding and nanofluid flooding with ogbono had oil recovery of $50.3 \%$. It took approximately $19.083 \mathrm{~min}$ for oil to be recovered after flooding $\mathrm{MgO}$ and Irvingia gabonensis into the core. Magnesium oxide as a nanoparticle from this experimental study had a good positive effect on oil recovery.
Table 5 Porosity and permeability of the core samples

\begin{tabular}{lllll}
\hline Samples & $\begin{array}{l}\text { Pore } \\
\text { volume } \\
\left(\mathrm{cm}^{2}\right)\end{array}$ & $\begin{array}{l}\text { Bulk volume } \\
\left(\mathrm{cm}^{2}\right)\left(\pi \mathrm{r}^{2} \mathrm{~h}\right)\end{array}$ & $\begin{array}{l}\text { Porosity }(\%) \\
\left(\frac{\text { pore volume }}{\text { bulk volume }}\right)\end{array}$ & $\begin{array}{l}\text { Perme- } \\
\text { ability } \\
(\mathrm{md})\end{array}$ \\
\hline $\mathrm{A}_{1} \mathrm{~F}$ & 24.59 & 38.33 & $0.6415=64.15$ & 11.25 \\
$\mathrm{~A}_{2} \mathrm{~F}$ & 27.90 & 40.01 & $0.6973=69.73$ & 18.56 \\
$\mathrm{~A}_{3} \mathrm{~F}$ & 25.44 & 65.64 & $0.3876=38.76$ & 17.34 \\
$\mathrm{~A}_{4} \mathrm{~F}$ & 30.02 & 70.99 & $0.4228=42.28$ & 19.73 \\
$\mathrm{~A}_{5} \mathrm{~F}$ & 28.51 & 82.52 & $0.3455=34.55$ & 20.25 \\
$\mathrm{~A}_{6} \mathrm{~F}$ & 27.34 & 51.00 & $0.5360=53.60$ & 14.34 \\
$\mathrm{~A}_{7} \mathrm{~F}$ & 28.60 & 48.07 & $0.5949=59.49$ & 18.65 \\
$\mathrm{~A}_{8} \mathrm{~F}$ & 24.49 & 63.95 & $0.3829=38.29$ & 19.45 \\
\hline
\end{tabular}

\section{Silicon oxide $\left(\mathrm{SiO}_{2}\right)$}

Table 7 shows the result of the silicon oxide. It was observed from Table 7 that waterflooding gave 6.4 and 7.2 mils out of 16.0 and 17.5 oil in place. Nanoparticle (silicon oxide) gave additional $0.9 \mathrm{mil}(5.6 \%)$. In addition, Irvingia gabonensis (ogbono) recovered 1.9 mils (10.9\%). Figure 7 shows that waterflooding with nanofluid has oil recovery of $45.6 \%$. Moreso, waterflooding with nanofluid and ogbono recovered oil of $52.0 \%$. This showed that silicon oxide plus ogbono is outstanding as a dispersing fluid. Flooding the formulated core with $\mathrm{SiO}_{2}$ and Irvingia gabonensis, time recovered was $16.03 \mathrm{~min}$, which shows that Silicon oxide has being known for its ability to change wettability of formation from oil-wet to water-wet.

\section{Aluminum oxide $\left(\mathrm{Al}_{2} \mathrm{O}_{3}\right)$}

Table 8 shows the result of aluminum oxide. However, aluminum oxide injection in core $\mathrm{A}_{5} \mathrm{~F}$ and $\mathrm{A}_{6} \mathrm{~F}$ had the highest oil recovery. Waterflooding recovered 6.7 and 8.5 mils out of 17.2 and 20.3 oil in place, respectively. Aluminum oxide recovered 1.5 mils (8.7\%), whereas aluminum oxide with ogbono recovered additional oil of 2.3
Table 4 Pore volume of the different samples

\begin{tabular}{lllll}
\hline Samples & $\begin{array}{l}\text { Weight of dry core } \\
\text { sample }(\mathrm{g})\end{array}$ & $\begin{array}{l}\text { Weight of saturated } \\
\text { core sample }(\mathrm{g})\end{array}$ & $\begin{array}{l}\text { Density of fluid }\left(\mathrm{g} / \mathrm{cm}^{2}\right) \\
(5000 \mathrm{ppm} \text { brine })\end{array}$ & $\begin{array}{l}\text { Pore volume }\left(\mathrm{cm}^{3}\right) \\
\left(\frac{\text { weight of saturated core }}{\text { density }}\right)\end{array}$ \\
\hline $\mathrm{A}_{1} \mathrm{~F}$ & 20.90 & 24.76 & 1.007 & 24.59 \\
$\mathrm{~A}_{2} \mathrm{~F}$ & 22.23 & 28.10 & 1.007 & 27.90 \\
$\mathrm{~A}_{3} \mathrm{~F}$ & 18.34 & 25.62 & 1.007 & 25.44 \\
$\mathrm{~A}_{4} \mathrm{~F}$ & 15.25 & 30.23 & 1.007 & 30.02 \\
$\mathrm{~A}_{5} \mathrm{~F}$ & 25.34 & 28.71 & 1.007 & 28.51 \\
$\mathrm{~A}_{6} \mathrm{~F}$ & 20.65 & 27.53 & 1.007 & 27.34 \\
$\mathrm{~A}_{7} \mathrm{~F}$ & 18.90 & 28.80 & 1.007 & 28.60 \\
$\mathrm{~A}_{8} \mathrm{~F}$ & 20.67 & 24.67 & 1.007 & 24.49 \\
\hline
\end{tabular}


Table 6 Result of the oil recovery with magnesium oxide $(\mathrm{MgO})$ nanofluid flooding

\begin{tabular}{lllll}
\hline S/No & Core $\mathrm{A}_{1} \mathrm{~F}$ (mil) & \multicolumn{3}{c}{ Core $\mathrm{A}_{2} \mathrm{~F}$ (mil) } \\
\hline 1 & Original oil in place (OOIP) & 16.0 & Original oil in place (OOIP) & 15.3 \\
2 & $\mathrm{~A}_{1} \mathrm{~F}+$ brine (waterflooding) & 5.9 & $\mathrm{~A}_{2} \mathrm{~F}+$ brine (waterflooding) & 6.2 \\
3 & $\mathrm{~A}_{1} \mathrm{~F}+$ brine $+\mathrm{MgO}$ & 0.2 & $\mathrm{~A}_{2} \mathrm{~F}+$ brine + MgO + Polymer (ogbono) & 1.5 \\
4 & $\begin{array}{c}\text { Total oil recovered (waterflooding and } \\
\text { nanofluid flooding) }\end{array}$ & 6.1 & $\begin{array}{c}\text { Total oil recovered (waterflooding and } \\
\text { nanofluid flooding plus ogbono) }\end{array}$ & 7.7 \\
5 & $\%$ oil recovered (waterflooding and & $\frac{6.1}{16.0} \times \frac{100}{1}=38.1 \%$ & $\%$ oil recovered (waterflooding and \\
& nanofluid flooding) & nanofluid flooding plus ogbono) & $\frac{7.7}{15.3} \times \frac{100}{1}=50.3 \%$ \\
\hline
\end{tabular}

Table 7 Result of the oil recovery with silicon oxide $\left(\mathrm{SiO}_{2}\right)$ nanofluid flooding

\begin{tabular}{lllll}
\hline Sample & Core $\mathrm{A}_{3} \mathrm{~F}(\mathrm{mil})$ & & Core $\mathrm{A}_{4} \mathrm{~F}(\mathrm{mil})$ \\
\hline 1 & Original oil in place (OOIP) & 16.0 & Original oil in place (OOIP) & 17.5 \\
2 & $\mathrm{~A}_{3} \mathrm{~F}+$ brine (waterflooding) & 6.4 & $\mathrm{~A}_{4} \mathrm{~F}+$ brine (waterflooding) & 7.2 \\
3 & $\mathrm{~A}_{3} \mathrm{~F}+$ brine $+\mathrm{SiO}_{2}$ & 0.9 & $\mathrm{~A}_{4} \mathrm{~F}+$ brine $+\mathrm{SiO}_{2}+$ Polymer (ogbono) & 1.9 \\
4 & $\begin{array}{l}\text { Total oil recovered (waterflooding and } \\
\text { nanofluid flooding) }\end{array}$ & 7.3 & Total oil recovered (waterflooding and & 9.1 \\
& $\%$ nanofluid flooding plus ogbono) & oil recovered (waterflooding and \\
5 & nanofluid flooding) & $\frac{7.3}{16.0} \times \frac{100}{1}=45.6 \%$ & $\%$ oil recovered (waterflooding and & $\frac{9.1}{17.5} \times \frac{100}{1}=52.0 \%$ \\
& & & nanofluid flooding plus ogbono) & \\
\hline
\end{tabular}

Table 8 Result of the oil recovery with aluminum oxide $\left(\mathrm{Al}_{2} \mathrm{O}_{3}\right)$ nanofluid flooding

\begin{tabular}{|c|c|c|c|c|}
\hline S/No & Core $\mathrm{A}_{5} \mathrm{~F}(\mathrm{mil})$ & & Core $\mathrm{A}_{6} \mathrm{~F}(\mathrm{mil})$ & \\
\hline 1 & Original oil in place (OOIP) & 17.2 & Original oil in place (OOIP) & 20.3 \\
\hline 2 & $\mathrm{~A}_{5} \mathrm{~F}+$ brine (waterflooding) & 6.7 & $\mathrm{~A}_{6} \mathrm{~F}+$ brine (waterflooding) & 8.5 \\
\hline 3 & $\mathrm{~A}_{5} \mathrm{~F}+$ brine $+\mathrm{Al}_{2} \mathrm{O}_{3}$ & 1.5 & $\mathrm{~A}_{6} \mathrm{~F}+$ brine $+\mathrm{Al}_{2} \mathrm{O}_{3}+$ Polymer (ogbono) & 2.3 \\
\hline 4 & $\begin{array}{l}\text { Total oil recovered (waterflooding and } \\
\text { nanofluid flooding) }\end{array}$ & 8.2 & $\begin{array}{l}\text { Total oil recovered (waterflooding and } \\
\text { nanofluid flooding plus ogbono) }\end{array}$ & 10.8 \\
\hline 5 & $\begin{array}{l}\% \text { oil recovered (waterflooding and } \\
\text { nanofluid flooding) }\end{array}$ & $\frac{8.2}{17.2} \times \frac{100}{1}=47.7 \%$ & $\begin{array}{c}\% \text { oil recovered (waterflooding and } \\
\text { nanofluid flooding plus ogbono) }\end{array}$ & $\frac{10.8}{20.3} \times \frac{100}{1}=53.2 \%$ \\
\hline
\end{tabular}

(11.3\%). Figure 8 shows the percentage of oil recovered for waterflooding and nanofluid (47.7\%), while waterflooding and nanofluids with ogbono had oil recovery of 53.2\% and time of oil recovery is $15.07 \mathrm{~min}$.

\section{Zinc oxide (ZnO)}

Table 9 shows the result of zinc oxide. The result form the table showed that zinc oxide had a significant effect on oil recovery as shown in core $\left(\mathrm{A}_{7} \mathrm{~F}-\mathrm{A}_{8} \mathrm{~F}\right)$. It was observed from the study that zinc oxide with ogbono worked well in increasing the viscosity of the displacing fluids which results in oil recovery. It was noted from Table 9 and Fig. 9 that waterflooding with zinc oxide (nanoparticles) had the least oil recovery of $35.1 \%$ when compared to nanofluids with ogbono having $52.4 \%$. This could be that waterflooding with zinc oxide does not significantly have effect on oil recovery but when added with ogbono greatly showed a positive result in oil recovery. Time of oil recovered is $18.45 \mathrm{~min}$. Table 10 shows the oil produced in barrels for the different nanofluids particles used in the experimental study (Fig. 10).

\section{A graph of waterflood and nanofluid flood with ogbono (Al203)}

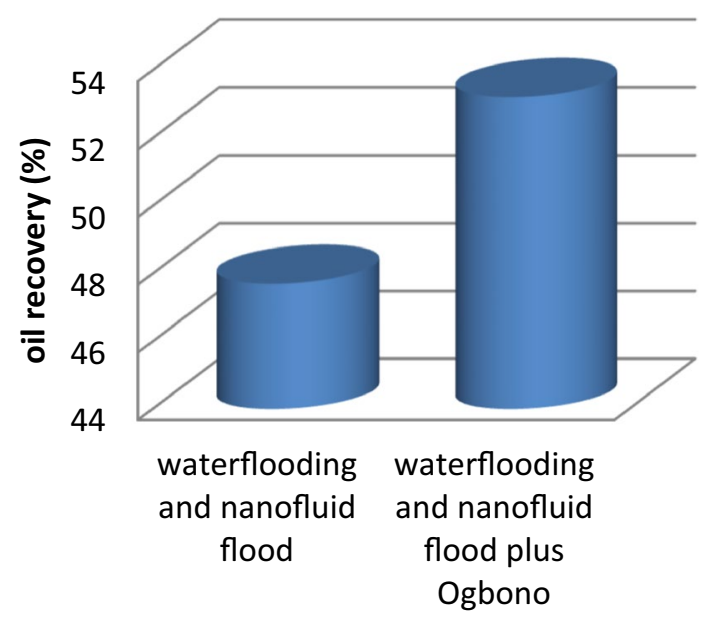

waterflood and nanofluid flood

Fig. 8 Oil recovery against waterflood and nanofluid flood 
Table 9 Result of the oil recovery with zinc oxide ( $\mathrm{ZnO}$ ) nanofluid flooding

\begin{tabular}{lllll}
\hline S/No & Core $\mathrm{A}_{7} \mathrm{~F}$ (mil) & \multicolumn{3}{c}{ Core $\mathrm{A}_{8} \mathrm{~F}(\mathrm{mil})$} \\
\hline 1 & Original oil in place (OOIP) & 18.5 & Original oil in place (OOIP) & 22.3 \\
2 & $\mathrm{~A}_{7} \mathrm{~F}+$ brine (waterflooding) & 6.2 & $\mathrm{~A}_{8} \mathrm{~F}+$ brine (waterflooding) & 9.7 \\
3 & $\mathrm{~A}_{7} \mathrm{~F}+$ brine $+\mathrm{ZnO}$ & 0.8 & $\mathrm{~A}_{8} \mathrm{~F}+$ brine + ZnO +Polymer (ogbono) & 2.0 \\
4 & Total oil recovered (waterflooding and & 6.5 & Total oil recovered (waterflooding and & 11.7 \\
& nanofluid flooding) & & nanofluid flooding plus ogbono) & \\
5 & \% oil recovered (waterflooding and & $\frac{6.5}{18.5} \times \frac{100}{1}=35.1 \%$ & $\%$ oil recovered (waterflooding and & $\frac{11.7}{22.3} \times \frac{100}{1}=52.4 \%$ \\
& nanofluid flooding) & & nanofluid flooding plus ogbono) & \\
\hline
\end{tabular}

\section{Agraph of waterflood and nanofluid fluid with ogbono} (Zno)

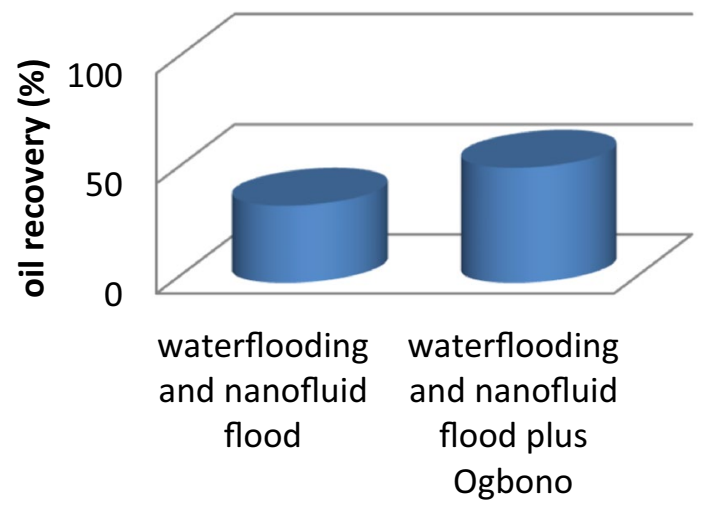

waterflood and nanofluid flood

Fig. 9 Oil recovery against waterflood and nanofluid flood

\section{Conclusion}

The following conclusions can be drawn from the study:

1. Irvingia gabonensis (ogbono) is a good displacing agent owing to its viscosity which decreases the mobility of the displacing fluid.

2. The combination of nanofluids and Irvingia gabonensis (ogbono) gave a higher oil recovery than that of waterflooding and nanoparticles.

3. Flooding with aluminum oxide nanoparticles and Irvingia gabonensis (ogbono) gave the highest oil recovery of $2.3 \mathrm{~m}^{3}$.

4. To achieve better oil recovery, the best sequence to use is waterflooding, followed by nanofluids flooding and finally polymer flooding.

5. Irvingia gabonensis could boost revenue generation to the government.

Table 10 Result comparison of oil produced in millimeter and barrel

Magnesium oxide $(\mathrm{MgO})$

\begin{tabular}{|c|c|c|c|c|c|}
\hline \multicolumn{3}{|l|}{$\mathrm{A}_{1} \mathrm{~F}+$ brine $+\mathrm{MgO}$} & \multicolumn{3}{|l|}{$\mathrm{A}_{2} \mathrm{~F}+$ brine $+\mathrm{MgO}+$ Polymer (ogbono) } \\
\hline Mils $\left(\mathrm{m}^{3}\right)$ & Barrels (bbl) & $\begin{array}{r}\text { Recovery } \\
\text { time (s) }\end{array}$ & Mils $\left(\mathrm{m}^{3}\right)$ & Barrels (bbl) & Recovery time(s) \\
\hline 0.2 & 0.03 & 1703 & 1.5 & 0.24 & 1145 \\
\hline \multicolumn{6}{|l|}{ Silicon oxide $\left(\mathrm{SiO}_{2}\right)$} \\
\hline $\mathrm{A}_{3} \mathrm{~F}+$ brine $+\mathrm{SiO}_{2}$ & & & $\mathrm{~A}_{4} \mathrm{~F}+$ brine $+\mathrm{SiO}_{2}+$ Polymer (ogbono) & & \\
\hline 0.9 & 0.14 & 1257 & 1.9 & 0.30 & 962 \\
\hline \multicolumn{6}{|c|}{ Aluminum Oxide $\left(\mathrm{Al}_{2} \mathrm{O}_{3}\right)$} \\
\hline $\mathrm{A}_{5} \mathrm{~F}+$ brine $+\mathrm{Al}_{2} \mathrm{O}_{3}$ & & & $\mathrm{~A}_{6} \mathrm{~F}+$ brine $+\mathrm{Al}_{2} \mathrm{O}_{3}+$ Polymer (ogbono) & & \\
\hline 1.5 & 0.24 & 1380 & 2.3 & 0.37 & 904 \\
\hline \multicolumn{6}{|l|}{ Zinc oxide $(\mathrm{ZnO})$} \\
\hline $\mathrm{A}_{7} \mathrm{~F}+$ brine $+\mathrm{ZnO}$ & & & $\mathrm{A}_{8} \mathrm{~F}+$ brine $+\mathrm{ZnO}+$ Polymer (ogbono) & & \\
\hline 0.8 & 0.13 & 1589 & 2.0 & 0.32 & 1107 \\
\hline
\end{tabular}

Hint: 42 gallons of oil $=1$ barrel of oil (bbl)

That is to say 21 gallons of oil will be 0.5 barrels of oil I barrels of oil $=0.158987294928 \mathrm{~m}^{3}=0.159 \mathrm{~m}^{3}$ 


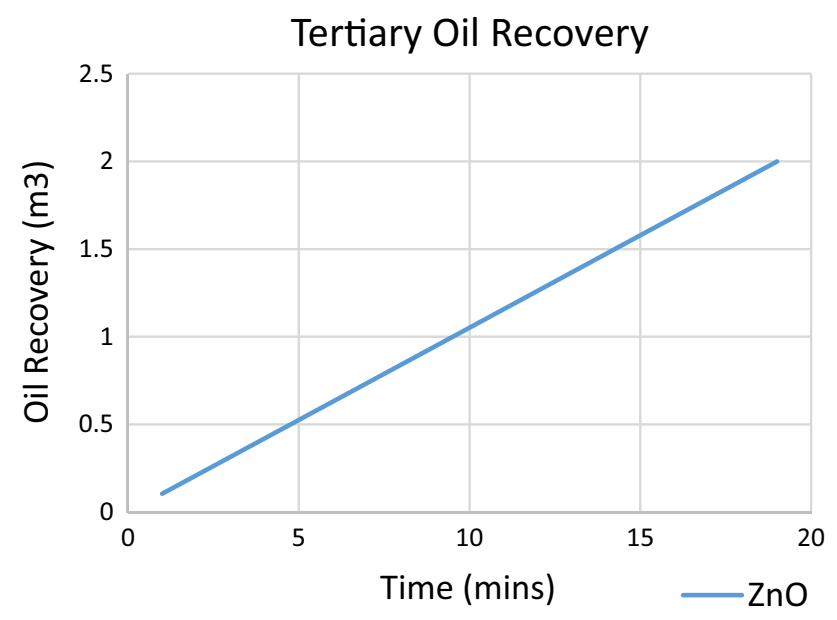

Fig. 10 Tertiary oil recovery for the combination of zinc oxide and ogbono (polymer) against time

6. Irvingia gabonensis is commercially available within the south eastern part of Nigeria. It will also encourage the production of local agro materials in the country (Figs. 11, 12 and 13 shows the oil recovery per time using each nanoparticle and the local agro material, agbono).

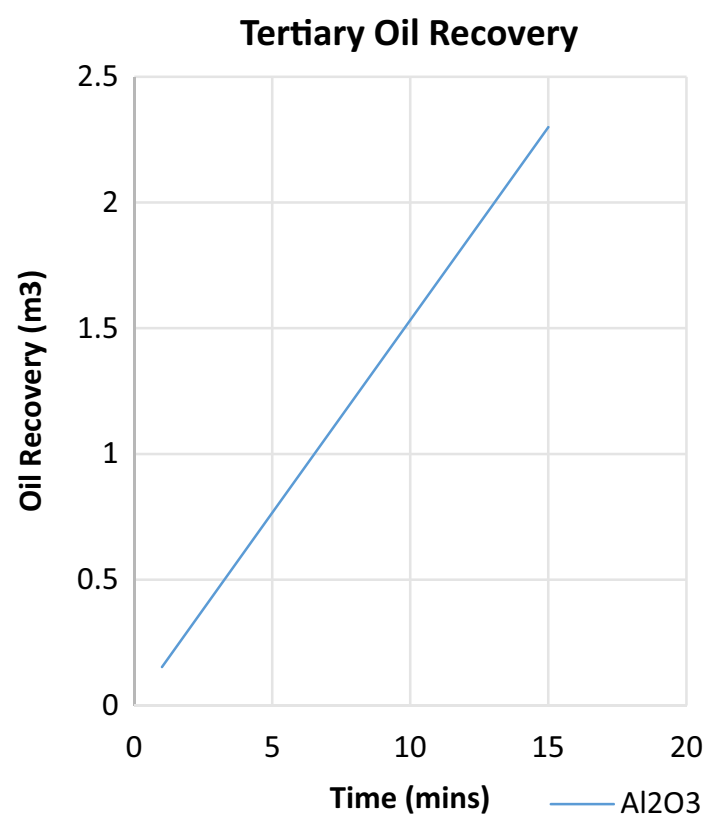

Fig. 12 Tertiary oil recovery for the combination of aluminum oxide and ogbono (polymer) against time

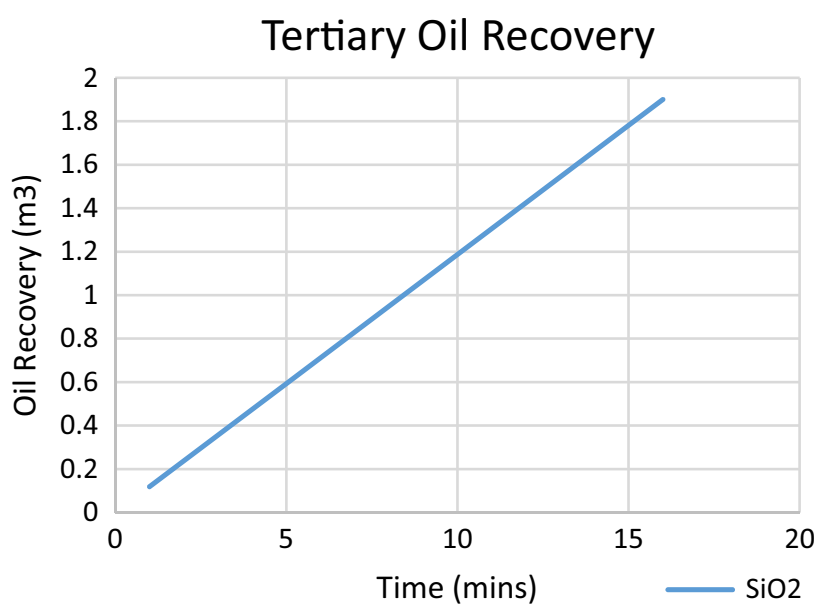

Fig. 11 Tertiary oil recovery for the combination of silicon oxide and ogbono (polymer) against time

\section{Observations}

1. Using Irvingia gabonensis (ogbono) as a dispersing medium of nanoparticles showed a positive effect on oil recovery in all the core samples used in the experiment.

2. The extracted oil from the ogbono was observed to cling on the walls of the collecting tube.

3. Aluminum oxide and magnesium oxide have a lot of bubbles at the effluent

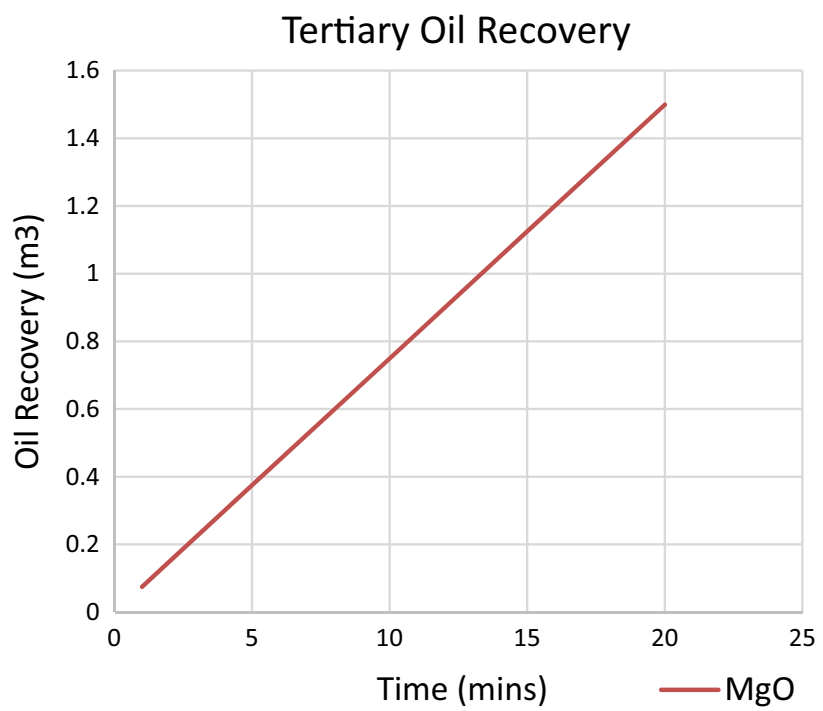

Fig. 13 Tertiary oil recovery for the combination of magnesium oxide and ogbono (polymer) against time 


\section{Contribution to knowledge}

Experimental study using Irvingia gabonensis (polymer) and nanoparticles to enhance oil recovery was established; and this will stem the need for more research on the use of nano-polymer flooding. The patronization of local content materials shows a very good performance, and it is much encouraged.

Acknowledgements The authors thanked the management of petroleum engineering department (FUTO) for availing their laboratory for the experimental analysis.

\section{Compliance with ethical standards}

Conflict of interest No conflict of interest exists between authors.

Open Access This article is licensed under a Creative Commons Attribution 4.0 International License, which permits use, sharing, adaptation, distribution and reproduction in any medium or format, as long as you give appropriate credit to the original author(s) and the source, provide a link to the Creative Commons licence, and indicate if changes were made. The images or other third party material in this article are included in the article's Creative Commons licence, unless indicated otherwise in a credit line to the material. If material is not included in the article's Creative Commons licence and your intended use is not permitted by statutory regulation or exceeds the permitted use, you will need to obtain permission directly from the copyright holder. To view a copy of this licence, visit http://creativecommons.org/licenses/by/4.0/.

\section{References}

Ahamdi M, Habibi A, Pourafhary (2013) Zeta-potential investigation and experimental study of nanoparticles deposited on rock surface to reduce fines migration. In: SPE 142633

Andreassen, L (2015) Nanoparticles effect on interfacial properties related to enhance oil recovery, norway, Unpublished MSc. Thesis Norwegian University of Science and Technology

Bennestien MV, Mogensen K (2014) Novel application of nanoparticles for future EOR. In: International Petroleum Technology Conference, Kuala Lumpur Malaysia

Chengara A, Nikolov A, Wasan DT, Trokhymchuck A, Henderson D (2004) Spreading of nanofluids driven by the structural disjoining pressure gradient. J Colloid Interface Sci 280:192-201

Das SK, Choi US, Yu W, Pradeep T (2008) Nanofluids science and technology. Wiley, Hoboken

Hendraningrat L, Torsaeter O (2014) Unlocking the potential of metal oxides nanoparticles to enhance operation recovery. In: Offshore technology conference, OTC—24696 MS Kuala Lumpur, Malaysia
Hendraningrat L, Engeset B, Suwarno S, Torsæter O (2012) Improved oil recovery by nanofluids flooding: an experimental study. In: SPE 163335

Hendraningrat L, Li S; Torsæter O (2013) A coreflood investigation of nanofluid enhanced oil recovery in low-medium permeability berea sandstone. In: SPE 164106

Huang T, Crews JB, Agrawal G (2009) Nanoparticle pseudo-crosslinked micella fluids: optimal solution for fluid-loss control with internal breaking. In: SPE international symposium and exhibition on formation damage control, Lafayette, Louisiana, USA, Paper No. 128067 - MS, pp 1-8

Luky H, Bjornar E, Suwarno S, Ole T (2012) Improved oil recovery by Nanofluids flooding; an experimental study. In: SPE 163335. Norwegian University of Science and Technology

Madhan T, Maghzi A, Kharrat R, Mohebbi A, Ghazanfari MH (2014) The impact of silica nanoparticles on the performance of polymer solution in presence of salts in polymer flooding for heavy oil recovery. Fuel 123:123-132. https://doi.org/10.1016/j. fuel.2014.01.017

Miranda CR, De Lara LS, Tonetto BX (2012) Stability and mobility of functionalized silica nanoparticles for enhanced oil recovery application. In: Paper SPE 157033-MS presented at SPE International Oilfield Technology Conference, 12-14 June, Noordwijk, The Netherlands. http://dx.doi.org/10.2118/157033-MS

Muhammed E (2016) Application of nanotechnology in EOR polymer-nano flooding in the nearest future of chemical EOR. In: SPE annual technical conference and exhibition, Dubai, UAE, SPE-184746

Nwldee L, Al-Anssari S, Barifcani A (2016) Nanofluids for enhance oil recovery processes: wettability alteration using zirconium oxide. In: Offshore technology conference OTC- 26573 Kuala Lumpur Malaysia

Ogolo NA, Olafuyi OA, Onyekonwu MO (2012) Enhanced oil recovery using nanoparticles. In: SPE 160847 paper presentation at the SPE Saudi Arabia Technical Symposium and Exhibition held in Al-Khobar, Saudi Arabia, 8-11 April 2012

Ogolo N, Onyekonwu M, Akaranta O (2013) Trapping mechanism of nanofluids on migrating fines in sand. In: SPE 167502 NAICE Lagos

Tola S, Sasaki K, Sugai Y (2017) Wettability alteration of sandstone with zinc oxide nanoparticle. In: 23rd formation evaluation symposium of Japan

Virkutyte J, Varma RS (2012) Environmentally friendly preparation of metal nanoparticles. In: Luque Rand Varma, RS (ed) Sustainable preparation of metal nanoparticles methods and application. Cambridge, United Kingdom

Wasan DT, Nikolov A, Kondiparty K (2011) The wetting and spreading of nanofluids on solids: role of the structural disjoining pressure. Curr Opin Colloid Interface Sci 16:344-349

Zhang T, Davidson D, Bryant SL, Huh C (2010) Nanoparticle-stabilized emulsions for applications in enhanced oil recovery. SPE 129885 